\title{
Sinonasal lymphomas in Indonesia: immunophenotype and Epstein-Barr virus association
}

\author{
Endang S.R. Hardjolukito , Antonius Nikolas Kurniawan ${ }^{*}$, Ria Kodariah ${ }^{*}$, Maria Francisca Ham $^{f}$, Wen-Juan Luo ${ }^{f}$, \\ Shin-Ichi Nakatsuka ${ }^{f}$, Katsuyuki Aozasa ${ }^{f}$
}

\begin{abstract}
Abstrak
Limfoma sinonasal merupakan kelainan yang jarang dijumpai yang mencakup jenis sel NK/T atau sel B. Penelitian2 terdahulu menunjukkan adanya perbedaan angka kejadian limfoma NK/T (LNKT) yang sesuai daerah geografis serta kaitan yang sangat tinggi dengan infeksi virus Epstein Barr. Penelitian yang dilakukan terhadap 4 l kasus penyakit limfoproliferatif sinonasal yang tersimpan di arsip Bagian Patologi Anatomik Fakultas Kedokteran Universitas Indonesia dalam kurun waktu 1994-2002 menunjukkan 35 kasus merupakan limfoma sinonasal. Pulasan imunohistokimia membuktikan 20 kasus (57\%) sebagai LNKT dan 15 kasus (43\%) limfoma sel $B$ jenis sel besar. LNKT menunjukkan laki2 lebih banyak dari wanita (L:W=4:1) serta usia yng lebih muda (median 37 tahun); sedangkan limfoma sel B lebih banyak pada wanita (1:1.5) serta usia yang lebih tua (median 49 tahun). Hasil pemeriksaan genom virus Epstein Barr dengan cara hibridisasi in situ menggunakan pelacak EBER-1 menunjukkan 90\% LNKT positif dan negatif pada semua limfoma sel B. Tulisan ini merupakan laporan limfoma sinonasal yang pertama dari Indonesia yang menunjukkan predominasi relatif limfoma sel $B$ dibandingkan dengan beberapa negara Asia lainnya. Tidak adanya kaitan dengan virus Epstein Barr pada limfoma sel B juga berbeda dengan penemuan di negara Asia lain (positivitas 25-4l\%). Predominasi limfoma sel B tanpa kaitan dengan virus Epstein Barr mengarah pada kemungkinan adanya faktor etiologik yang spesifik untuk Indonesia. (Med J Indones 2004; 13: 71-6)
\end{abstract}

\begin{abstract}
Sinonasal lymphoma is a rare disease with NK/T-cell (NKTC) or B-cell immunophenotype. Previous study revealed the geographic difference in frequency of NKTC lymphoma (NKTCL) and almost constant association with Epstein-Barr virus (EBV) infection. Through review of 41 cases with sinonasal lymphoproliferative diseases registered in the Department of Anatomical Pathology, University of Indonesia during the period 1994 to 2002, thirty-five were accepted as sinonasal lymphoma. Immunohistochemistry revealed that 20 cases (57\%) were NK/T-cell type and 15 (43\%) B-cell type with large cell morphology, i.e.,diffuse large B-cell lymphoma. NKTCL showed a marked male preponderance $(M / F=4: 1)$ and younger onset of disease (median age, 37 years), and $B$ cell lymphoma showed a relative female preponderance (1:1.5) and older disease onset (median age, 49 years). In situ hybridization using EBER-1 probe revealed that $90 \%$ of NKTCL were EBV-positive, but none of B-cell lymphoma were EBV-positive. This is the first report on sinonasal lymphoma in Indonesia showing relative predominance of B-cell lymphoma compared to other Asian countries and Peru (14-24\%). Lack of EBV-association in Indonesian sinonasal B-cell lymphoma showed a marked contrast to that in other Asian countries (EBV positive rate, 25-41\%). Predominance of sinonasal B-cell lymphoma without EBV genome might suggest presence of specific etiologic factors in Indonesia. (Med J Indones 2004; 13: 71-6)
\end{abstract}

Keywords: sinonasal lymphoma, B-cell, NK/T-cell, Epstein-Barr virus, Indonesia

Sinonasal lymphoma is a relatively rare disease, and represented $2 \%$ and $6.8 \%$ of all extranodal lymphomas in the series reported from North America by Freeman

\footnotetext{
* Department of Anatomical Pathology, Faculty of Medicine, University of Indonesia / Dr.Cipto Mangunkusumo National Central General Hospital, Jakarta, Indonesia.

${ }^{f}$ Department of Pathology (C3), Osaka University Graduate School of Medicine, 2-2 Yamadaoka, Suita, Osaka 565-0871, Japan
}

et $\mathrm{al}^{1}$ and Japan by us. ${ }^{2}$ Sinonasal lymphoma presents with tumorous lesions in the upper respiratory tract with or without necrotic and granulomatous appearances. In the former case, the disease is termed as lethal midline granuloma (LMG). Immunophenotypically sinonasal lymphoma could be divided into NK/T-cell and B-cell type. NK/T-cell lymphoma (NKTCL) frequently presents as LMG and histologically shows a polymorphous pattern of proliferation, consisting of large atypical cells, small lymphocytes, plasma cells, benign-appearing macrophages, neutrophils and much 
less frequently eosinophils. ${ }^{3,4}$ Majority of sinonasal NKTCL was previously diagnosed as polymorphic reticulosis because of its polymorphous pattern of proliferation. This type of lymphoma is characterized by positive immunoreactivity for NK-cell marker CD56, lack of expression of surface CD3 but presence of cytoplasmic $\mathrm{CD} 3 \varepsilon$, and infrequent expression of other T-lineage markers such as CD 4 and CD8. ${ }^{3,4}$ Whereas sinonasal B-cell lymphoma usually shows monomorphous pattern of proliferation. ${ }^{5}$

Recently sinonasal NKTCL draw attention of investigators, because of its association with EpsteinBarr virus (EBV) ${ }^{6}$ and clustering of patients in the Asian countries ${ }^{7,8}$ and Central and South American countries. ${ }^{9}$ Our previous patho-epidemiological study revealed that frequency of sinonasal NKTCL is much higher in east Asian countries than in England but the frequency is different by district: highest in Korea. ${ }^{7,8}$ However the frequency in Korea showed the marked decrease in the recent years. ${ }^{10}$ Majority of sinonasal NKTCL is EBV-positive in every Asian countries and also in other areas of the world. ${ }^{6-9}$ These findings suggest that EBV together with environmental factors might be causative for this disease. Meanwhile information for epidemiological features of sinonasal B-cell lymphoma is limited until present.

In the present study, we examined the immunophenotypic profiles in 35 cases with sinonasal lymphomas from Jakarta, Indonesia together with the presence of EBV j;defined by in situ hybridization.

\section{METHODS}

Forty-one cases with sinonasal lymphoproliferative diseases which were registered in the Department of Anatomical Pathology, Faculty of Medicine, University of Indonesia / Dr.Cipto Mangunkusumo National Central General Hospital, Jakarta during the period 1994 to 2002 were selected for the present study. Biopsy specimens obtained from the sinonasal lesions of these cases were fixed in $10 \%$ formalin and routinely processed for paraffin embedding. Histologic sections, cut at $4 \mu \mathrm{m}$, were stained with hematoxylineosin and immunoperoxidase procedures (ABC method). Through review of the histologic sections, diagnosis of sinonasal lymphomas was made in 35 cases. Brief clinical information such as age and sex of patients and roentgenographic findings of the face were available. Histologic sections did not contain representative lymphomatous lesions in the remaining
6 cases, thus these cases were excluded from the further analysis. In situ hybridization for detection of EBV DNA was also carried out.

\section{Immunohistochemistry}

Immunohistochemical study on the paraffin-embedded sections was carried out using ABC method. Primary antibodies used in this study, their supplier and dilutions were as follows: anti-CD3 (Dakopatts, Glostrup, Denmark,1:100), CD4 (Novocastra, Newcastle, UK,1:200), CD8 (Dakopatts,1:200), CD20 (Kyowa Medex, Tokyo, Japan,1:50), CD45RO (Dakopatts, 1:100), CD56 (Zymed, South San Fransisco, CA,1:40) and TIA-1 (Coulter, Hialeah, FL,1:500). Sections were treated with $0.1 \%$ trypsin solution (Sigma, St. Louis, MO) at $37^{\circ} \mathrm{C}$ for 30 min before reaction with anti-CD3. When CD56 was used as primary antibody, sections in $10 \mathrm{mM}$ citrate buffer $(10 \mathrm{mM}$ citrate monohydrate in distilled water, $\mathrm{pH}$ 6.0) were treated with a microwave oven for $15 \mathrm{~min}$ for antigen retrieval. Subsequently the sections were incubated with primary antibodies at $4^{\circ} \mathrm{C}$ overnight, and incubated with biotinylated horse anti-mouse $\operatorname{IgG}$ antibody (Vector Labs., Burlingame, CA). After treatment with $3 \%$ hydrogen peroxidase solution to reduce endogenous peroxidase activity, sections were incubated with peroxidase-conjugated avidin-biotin complex (Vectastain ABC kit, Vector Labs.) followed by visualization in $0.03 \%$ diaminobenzidine solution.

\section{In situ hybridization for EBV}

The in situ hybridization procedures were performed as previously described with some modifications. ${ }^{11}$ Briefly, 30-base sense and antisense oligonucleotide probes corresponding to a portion of the EBVencoded early RNA 1 (EBER-1) gene, a region of the EBV genome that is actively transcribed in latently infected cells were synthesized. As a positive control, a case of proven EBER-1 positive nasal NKTCL was used. As negative controls, hybridization was performed with antisense probe after RNase (Sigma) treatment.

\section{Statistical analysis}

Differences in frequency of B-cell lymphoma among sinonasal lymphoma and EBV positive rate between cases from Indonesia and other countries were examined by Fisher's test. 


\section{RESULTS}

\section{Pathological findings}

Among 35 cases of sinonasal lymphoma, 20 cases (57 $\%$ ) showed $\mathrm{CD} 20^{-}$and $\mathrm{CD} 3 \varepsilon^{+}, \mathrm{CD}^{+}, \mathrm{CD} 45 \mathrm{RO}^{+}$, $\mathrm{CD}^{+} 6^{+}$and/or TIA- $1^{+}$, thus were judged as NK/T-cell lymphoma. Remaining 15 (43 \%) showed CD20 ${ }^{+}$, $\mathrm{CD} 3 \varepsilon^{-}, \mathrm{CD}^{-}, \mathrm{CD}^{-}, \mathrm{CD}^{-} 6^{-}$, TIA-1 ${ }^{-}$, thus judged as Bcell lymphoma. Positive immunoreactivity for CD4 was found in one of 20 cases with NKTCL. One of Bcell lymphoma was positive for CD45RO.

Histologically, necrosis of varying degrees was a constant finding in NKTCL and B-cell lymphoma. In NKTCL, there was a diffuse proliferation of large atypical mono- or multinucleated cells with varying number of lymphocytes, plasma cells, macrophages, neutrophils and much less frequently eosinophils. Proliferation of large atypical cells in and perivascular walls, so-called angiocentric pattern, was occasional. Meanwhile B-cell lymphoma showed a monomorphous pattern of proliferation of large cells, thus classified as diffuse large B-cell lymphoma (DLBL) (Fig.1). Mitotic figures were variable among the cases.

\section{Clinical findings}

The NK/T-cell lymphoma showed a marked male preponderance, while B-cell lymphoma showed a female preponderance (Table 1). Mean age at the time of diagnosis was younger in NKTCL than in B-cell lymphoma cases. Roentgenographically, involvement of paranasal sinuses was rather frequent in B-cell than in NK/T-cell lymphoma.

Table 1. Brief findings of sinonasal NK/T-cell and B-cell lymphoma

\begin{tabular}{lcc}
\hline & \multicolumn{2}{c}{ Sinonasal lymphoma } \\
\cline { 2 - 3 } & $\begin{array}{c}\text { NK/T-cell type } \\
(\mathrm{n}=20)\end{array}$ & $\begin{array}{c}\text { B-cell type } \\
(\mathrm{n}=15)\end{array}$ \\
\hline Male/Female & $4: 1$ & $1: 1.5$ \\
Mean age (range) & $37(6-67)$ & $49(6-76)$ \\
Main site of involvement & & \\
$\quad$ Nasal cavity & 16 & 5 \\
$\quad$ Paranasal sinuses & 3 & 2 \\
$\quad$ Nasopharynx & 1 & $0 / 15(0 \%)$ \\
EBV positive rate & $18 / 20(90 \%)$ & \\
\hline
\end{tabular}




\section{In situ hybridization for EBV genomes}

EBV DNA was detected in the nucleus of the proliferating cells in 18 (90\%) of 20 NKTCL cases
(Fig.2). Whereas any positive signals could not be detected in all 15 cases of B-cell lymphoma. The difference in EBV positive rate between cases with NKTCL and B-cell lymphoma is significant $(\mathrm{p}<0.0001)$

Figure 2 A. Sinonasal NK/T-cell lymphoma with polymorphous pattern of proliferation consisting of large atypical cells, small lymphocytes, and plasma cells. Hematoxylin and eosin (HE), X 400 


\section{DISCUSSION}

NKTCL is the predominant type of sinonasal lymphoma, constituting more than three fourth of all sinonasal lymphomas in Asian ${ }^{12}$ and central American countries. ${ }^{9}$ The present study reveals the interesting results that the proportion of B-cell lymphoma among all sinonasal lymphomas is higher in Indonesia (43\%) than that reported from Korea $(8 / 33: 24 \%)^{12}(\mathrm{p}=0.08)$ and Peru (2/14:14 \%) (personal communication) $(\mathrm{p}=0.055)$. Meanwhile B-cell lymphomas, mostly DLBL, were predominant type of sinonasal lymphomas in Western countries constituting $62 \%-76 \%$ of all cases of sinonasal lymphomas. ${ }^{13,14}$ All of the present series of B-cell lymphomas were DLBL.

Median age at the time of diagnosis in B-cell lymphoma (49 years) was older than that in NKTCL (37 years) in the present cases, which is a common finding in sinonasal lymphomas irrespective of countries; more than 10 years older in B-cell than in NKTCL cases. ${ }^{12,14,15}$ The gender preponderance in these two subsets of lymphoma is also different: the NKTCL showed a marked male preponderance (4:1), while the B-cell lymphoma showed female preponderance (1:1.5). In other Asian countries and Western countries, both the NKTCL and B-cell lymphoma showed the male preponderance. ${ }^{7,12}$

Sinonasal NKTCL is one of EBV-associated lymphomas; the previous study using in situ hybridization with EBER-1 probe showed that ninety percent or more cases were EBV positive. ${ }^{5,9,12,14,15}$ Ninety percent of the present cases with NKTCL was also EBV-positive. Previous study showed that EBVpositive B-cell lymphomas usually show the large cell morphology, i.e., DLBL. All of the present cases with sinonasal B-cell lymphoma were diffuse large cell lymphoma but none of these cases were EBV positive. EBV positivity in sinonasal B-cell lymphoma was reported to be low in Western countries: two of 11 (18\%) cases reported from the Massachusetts General Hospital was EBV positive. ${ }^{16}$ Whereas EBV positive rate in sinonasal B-cell lymphoma in Japan (9/22: $41 \%$ ) was significantly higher than that in Indonesian cases $(p<0.01) .^{5}$ One of four Korean cases with sinonasal B-cell lymphoma was EBV positive. ${ }^{12}$

Recently we reported the different frequencies of p53 and c-kit gene mutations among sinonasal NKTCL in China and Japan. ${ }^{16,17}$ These findings suggest racial, environmental, or life style differences to be a possible cause of sinonasal tumorigenesis. Outnumbering of sinonasal lymphoma of B-cell type without EBV genome might suggest presence of specific etiologic factors in Indonesia. Because the different etiologic factors might cause different patterns of gene mutations, we are now preparing mutation analysis of oncogenes and tumor suppressor genes in cases of sinonasal lymphoma from Indonesia.

\section{REFERENCES}

1. Freeman C, Berg JW, Cutler SJ: Occurrence and prognosis of extranodal lymphomas. Cancer 1972; 29:252-60.

2. Aozasa K, Tsujimoto M, Sakurai M, Honda M, Yamashita K, Hanada M, Sugimoto A: Non-Hodgkin`s lymphomas in Osaka, Japan. Eur J Cancer Clin Oncol 1985; 21:487-92.

3. Jaffe ES: Classification of natural killer (NK) cell and NK-like T-cell malignancies. Blood 1996; 87:1207-10.

4. Ohsawa M, Nakatsuka S, Kanno H, Miwa H, Kojya S, Harabuchi Y, Yang W-I, Aozasa K: Immunophenotypic and genotypic characterization of nasal lymphoma with polymorphic reticulosis morphology. Int J Cancer 1999; 81: 865-70.

5. Tomita Y, Ohsawa M, Mishiro Y, Kubo T, Maeshiro N, Kojya S, Noda Y, Aozasa K: The presence and subtype of Epstein-Barr virus in $\mathrm{B}$ and $\mathrm{T}$ cell lymphomas of the sino-nasal region from the Osaka and Okinawa districts of Japan. Lab Invest 1995;73:190-6.

6. Harabuchi Y, Yamanaka N, Kataura A, Imai S, Kinoshita T, Mizuno F, Osato T: Epstein-Barr virus in nasal T-cell lymphoma in patients with lethal midline granuloma. Lancet 1990; 335: 128-30.

7. Aozasa K, Ohsawa M, Tajima K, Sasaki R, Maeda H, Matsunaga T, Friedmann I: Nation-wide study of lethal mid-line granuloma in Japan: frequencies of Wegener's granulomatosis, polymorphic reticulosis, malignant lymphoma and other related conditions. Int J Cancer 1989; 44:63-6.

8. Aozasa K, Yang WI, Lee YB, Pan WS, Wu YF, Horiuchi $\mathrm{K}$, Hyun $\mathrm{BH}$ and Tajima $\mathrm{K}$ : Lethal midline granuloma in Seoul (Korea) and Shanghai (China). Int J Cancer 1992; $52: 673-4$.

9. Arber DA, Weiss LM, Albujar PF, Chen YY, Jaffe ES: Nasal lymphomas in Peru. High incidence of T-cell immunophenotype and Epstein-Barr virus infection. Am J Surg Pathol 1993; 17:392-9.

10. Ohsawa M, Shingu N, Inohara H, Kubo T, Yang WI, Yoon JH, Aozasa K: Chronological changes in incidences of polymorphic reticulosis in Korea and Japan. Oncol 1999; 56:202-7.

11. Weiss LM, Chen YY, Liu XF, Shibata D: Epstein-Barr virus and Hodgkin's disease: a correlative in situ hybridization and polymerase-chain-reaction study. Am J Pathol 1991;139:1259-65.

12. Tomita Y, Ohsawa M, Qiu K, Hashimoto M, Yang WI, Kim GE, Aozasa K: Epstein-Barr virus in lymphoproliferative diseases in the sino-nasal region: close association with $\mathrm{CD}^{-} 6^{+}$immunophenotype and polymorphic reticulosis morphology. Int J Cancer 1997; 70:9-13. 
13. Fellbaum C, Hansmann ML, Lennert K: Malignant lymphomas of the nasal cavity and paranasal sinuses. Virchows Arch A Pathol Anat Histopathol 1989; 414:399405.

14. Cuadra-Garcia I, Proulx GM, Wu CL, Wang CC, Pilch BZ, Harris NL, Ferry JA: Sinonasal lymphoma: a clinicopathologic analysis of 58 cases from the Massachusetts General Hospital. Am J Surg Pathol 1999; 23:1356-69.

15. Cheung MM, Chan JK, Lau WH, Foo W, Chan PT, Ng CS, Ngan RK: Primary non-Hodgkin`s lymphoma of the nose and nasopharynx: clinical features, tumor immunophenotype, and treatment outcome in 113 patients. J Clin Oncol 1998 16:70-7.

16. Li T, Hongyo T, Syaifudin M, Nomura T, Dong Z, Shingu N, Kojya S, Nakatsuka S, Aozasa K: Mutations of the p53 gene in nasal NK/T-cell lymphoma. Lab Invest 2000; 80:493-9.

17. Hongyo $\mathrm{T}$, Li $\mathrm{T}$, Syaifudin $\mathrm{M}$, Baskar R, Ikeda $\mathrm{H}$, Kanakura Y, Aozasa K, Nomura T: Specific c-kit mutations in sinonasal NK/T-cell lymphoma in China and Japan. Cancer Res 2000; 60: 2345-7. 